\title{
MAXIMIZING WHEAT YIELD THROUGH INTEGRATED USE OF FARMYARD MANURE AND FERTILIZERS
}

\author{
S. C. Tripathi", Subhash Chander and Raj Pal Meena \\ ICAR-Indian Institute of Wheat and Barley Research, Karnal -132 001, Haryana, India
}

\begin{abstract}
A field experiment was done for two consecutive years from 2010-11 to 2011-12 with two varieties of wheat (DBW 17 and DPW 621-50) and ten treatments of fertilizer, involving NPK, FYM and micronutrient, with an objective to maximize the crop yield. Results showed that variety DBW 17 recorded significantly higher grain yield $(4.93 \%)$, straw yield $(6.31 \%)$ and $\mathrm{HI}(1.12 \%)$ as compared to DPW $621-50$. There was no significant difference in yield attributes between two varieties. Application of $150 \%$ recommended NPK fertilizers produced the maximum grain yield $(6.10 \mathrm{t}$ ha $^{-1}$ ), which was $7.7 \%$ higher over the $100 \%$ NPK fertilizers, followed by $15 \mathrm{t} \mathrm{ha}^{-1}$ FYM application along with $150\left(5.98 \mathrm{t} \mathrm{ha}^{-1}\right)$ and $125 \%(5.96 \mathrm{t}$ $\mathrm{ha}^{-1}$ ) NPK application. There had no significant effect of micronutrients ( $\mathrm{Zn}, \mathrm{Cu}, \mathrm{Fe} \& \mathrm{Mn}$ ) on wheat yield indicating that the soil was not deficient in those micronutrients. A significant variation was observed between two years in respect of yield and yield attributes, higher performances being recorded in 2011-12. Crop lodging was observed, with a maximum lodging of $26.4 \%$ causing a yield reduction of up to $9.9 \%$. Agronomic efficiency was the maximum (13.64 $\mathrm{kg}_{\text {grain }} \mathrm{kg}^{-1}$ fertilizer) with the recommended rate of fertilizers and it decreased with increasing rates. Addition of FYM didn't increase the agronomic efficiency due to inclusion of $75 \mathrm{~kg} \mathrm{~N}$ contribution from $15 \mathrm{t} \mathrm{ha}^{-1}$ of FYM.
\end{abstract}

Keywords: Agronomic efficiency, FYM, micronutrient, NPK, wheat

\section{INTRODUCTION}

In India, wheat (Triticum aestivum L.) is the second most important food crop after rice, with an average yield of 3.07 t ha ${ }^{-1}$ as recorded in 2013-14 and in Punjab the yield was $4.85 \mathrm{t} \mathrm{ha}^{-1}$. Scope exists to maximize spring wheat productivity with the use of higher rates of chemical fertilizers. In India, present day cultivated spring wheat varieties are cultivated with use of moderate level of $N\left(120 \mathrm{~kg} \mathrm{ha}^{-1}\right)$. These spring wheat cultivars, however, tend to lodge when exposed to higher levels of fertilization of $180 \mathrm{~kg} \mathrm{~N} \mathrm{ha}^{-1}$ or more (Tripathi et al., 2004). Consequently, the realizable yields of present varieties even under the best management are pegged at

* Corresponding author email: subhtripathi@gmail.com

Received: 24.04 .2016 
5.0 to $5.5 \mathrm{t} \mathrm{ha}^{-1}$ only. Farmers in India have started using $\mathrm{N}$ rates beyond $150-180 \mathrm{~kg}$ $\mathrm{ha}^{-1}$ to realize higher yields, but this creates a probability of lodging. To avoid lodging sometimes farmers skip the last irrigation (Hobbs et al., 1997), which is crucial for grain filling and ultimately limiting the wheat yield. This is practiced in India due to high wind velocity during grain filling period, flat system of planting, application of flood irrigation and non-availability of lodging resistant genotypes with higher $\mathrm{N}$ application. Increasing the nitrogen doses beyond a certain limit induces the lodging and ultimately affecting the grain yield and its attributes. The grain yield reduction ranges from 7 to $35 \%$ due to culm lodging with the greatest effect when it occurs within the first 20 days after anthesis (Fischer and Stapper, 1987) and up to $8.9 \%$ in high yielding wheat varieties even after 25 days after anthesis (Tripathi et al., 2004). Lodging behavior of wheat at different $\mathrm{N}$ levels was studied by Kheiralla et al. (1993) from Egypt and they reported increased lodging from $3 \%$ at lower $\mathrm{N}$ application $\left(125 \mathrm{~kg} \mathrm{ha}^{-1}\right)$ to $33 \%$ at higher $\mathrm{N}$ application $(275$ $\left.\mathrm{kg} \mathrm{ha}^{-1}\right)$. Integrated use of organic and inorganic sources of nutrient may support enhanced yield of wheat (Kumara et al., 2013).

To meet the increasing "food grain needs" it is imperative to maximize wheat yield through use of higher $\mathrm{N}$ levels and suitable genotypes having consistent stable performance at high level of nitrogen. Hobbs et. al. (1997) pointed out that a wheat crop requires more than $300 \mathrm{~kg}$ of $\mathrm{N}$ for a target grain yield of $7 \mathrm{t} \mathrm{ha}^{-1}$. The authors assumed that the soils have a capacity to produce at least $2 \mathrm{t} \mathrm{ha}^{-1}$ grain yield without $\mathrm{N}$ application with a $50 \% \mathrm{~N}$ use efficiency. Therefore, it is important to formulate the best management practices in order to achieve the maximum possible grain yield. The present study was carried out with the objective of achieving the maximum yield of different varieties of wheat through integrated use of farm yard manure and chemical fertilizers including micronutrients and varieties.

\section{MATERIALS AND METHODS}

A field study was conducted for two consecutive years from 2010-11 to 201112 at the Indian Institute of Wheat and Barley Research, Karnal (Latitude $29^{\circ} 43^{\prime} \mathrm{N}$, longitude $76^{\circ} 58^{\prime} \mathrm{E}$ and altitude $245 \mathrm{~m}$ above mean sea level). The experimental soil was sandy clay loam in texture (15\% clay), alkaline $\mathrm{pH}(8.1)$, low in organic carbon $(0.35 \%)$ and available $\mathrm{N}\left(141 \mathrm{~kg} \mathrm{ha}^{-1}\right)$, medium in available $\mathrm{P}\left(16.8 \mathrm{~kg} \mathrm{ha}^{-1}\right)$ and available $\mathrm{K}\left(165 \mathrm{~kg} \mathrm{ha}^{-1}\right)$ content. The available micronutrients content of the field soil $(0-15 \mathrm{~cm})$ was $1.26,47.92,19.75$ and $2.45 \mathrm{mg} \mathrm{kg}^{-1}$ of $\mathrm{Zn}, \mathrm{Fe}, \mathrm{Mn}$ and $\mathrm{Cu}$, respectively, which were medium ( $\mathrm{Zn}$ ) to high $(\mathrm{Fe}, \mathrm{Mn}$ and $\mathrm{Cu}$ ). The layout consists of two main plots i.e. wheat variety DBW 17 and DPW 621-50 and ten sub plots arranged in a split plot design with three replications. The sub-plots contained 100, 125 and $150 \%$ recommended fertilizers, combined with or without $15 \mathrm{t} \mathrm{ha}^{-1}$ FYM plus $0.5 \%$ micronutrient spray ( $\mathrm{Zn}, \mathrm{Fe}, \mathrm{Cu}$ and $\mathrm{Mn}$ mixed) for fertilizer \& manure treatments and one control. Recommended (100\%) fertilizer dose was $150 \mathrm{~N}, 60 \mathrm{P}_{2} \mathrm{O}_{5}$ and 40 $\mathrm{K}_{2} \mathrm{O} \mathrm{kg} \mathrm{ha}{ }^{-1}$. No fertilizer or FYM was added to the control plots. Previous crop was 
rice (variety Gobind) under puddled transplanted condition. FYM (15 $\left.\mathrm{t} \mathrm{ha}^{-1}\right)$, containing $0.5 \%$ nitrogen, was incorporated into the soil at the time of field preparation. Wheat seeds were sown at a rate of $100 \mathrm{~kg} \mathrm{ha}^{-1}$ during the first week of November each year. All of phosphorus (as DAP), potassium (as MOP) and 1/3rd nitrogen (as urea) were applied at the time of sowing as basal dose; the second 1/3rd $\mathrm{N}$ was applied at first node stage (40 DAS) and the remaining $1 / 3 \mathrm{rd} \mathrm{N}$ was supplied at booting stage. Micronutrients spray @ 0.5\% each ( $\mathrm{Zn}, \mathrm{Fe}, \mathrm{Cu}$ and $\mathrm{Mn}$ mixed) was done at booting stage. Weeds were controlled by use of sulfosulfuron at $25 \mathrm{~g} \mathrm{ha}^{-1}$ in 400 liters water at 30-35 DAS. Irrigation was done as per need of the crop. Lodging was recorded as a \% of net plot area. Biomass, grain yield and yield attributing parameters were recorded and analyzed on yearly as well as pooled basis. Agronomic efficiency ( $\mathrm{kg}$ grain $\mathrm{kg}^{-1}$ fertilizer) was calculated as per standard procedure and contribution from FYM i.e. $75 \mathrm{~kg} \mathrm{~N}$ was considered to the total fertilizer. The grain yield from control plot was subtracted from the treatments and then divided by added fertilizer for calculating agronomic efficiency.

\section{RESULTS}

Varietal difference in grain yield, straw yield and HI was significant whereas yield attributing parameters like earhead $\mathrm{m}^{-2}$, grains earhead ${ }^{-1}$ and 1000-grain weight and grains $\mathrm{m}^{-2}$ were comparable between two varieties. Pooled analysis showed that variety DBW 17 recorded significantly higher grain yield $(4.93 \%)$, straw yield (6.31\%) and HI (1.12\%) as compared to DPW 621-50. The variety DBW 17 produced significantly higher grain yield, straw yield and HI (Table 1).

Table 1. Effects of varieties, fertilizer rates , FYM and micronutrients on grain yield, straw yield and harvest index of wheat

\begin{tabular}{|c|c|c|c|c|c|c|c|c|c|}
\hline \multirow[t]{2}{*}{ Factors } & \multicolumn{3}{|c|}{ Grain Yield $\left(\mathrm{t} \mathrm{ha}^{-1}\right)$} & \multicolumn{3}{|c|}{ Straw Yield $\left(\mathrm{t} \mathrm{ha}^{-1}\right)$} & \multicolumn{2}{|c|}{$\mathrm{HI}$} & \multirow[b]{2}{*}{ Pooled } \\
\hline & 2010-11 & 2011-12 & Pooled & $\begin{array}{c}2010- \\
11\end{array}$ & $\begin{array}{c}2011- \\
12\end{array}$ & Pooled & $\begin{array}{c}2010- \\
11\end{array}$ & $\begin{array}{c}2011- \\
12\end{array}$ & \\
\hline \multicolumn{10}{|l|}{ Varieties } \\
\hline DBW 17 & 5.17 & 5.90 & 5.53 & 11.20 & 9.01 & 10.11 & 0.324 & 0.396 & 0.360 \\
\hline DPW 621-50 & 4.81 & 5.72 & 5.27 & 9.27 & 9.74 & 9.51 & 0.343 & 0.368 & 0.356 \\
\hline $\mathrm{CD}(\mathrm{P}=0.05)$ & NS & 0.08 & 0.11 & 0.78 & 0.43 & 0.18 & 0.003 & 0.001 & 0.001 \\
\hline \multicolumn{10}{|l|}{$\begin{array}{l}\text { Fertilizer } \\
\text { treatments }\end{array}$} \\
\hline $100 \% \mathrm{NPK}$ & 5.29 & 5.97 & 5.63 & 9.45 & 9.37 & 9.41 & 0.359 & 0.390 & 0.375 \\
\hline $\begin{array}{l}100 \% \mathrm{NPK}+15 \mathrm{t} \\
\mathrm{ha}^{-1} \mathrm{FYM}\end{array}$ & 5.47 & 6.00 & 5.74 & 10.70 & 9.80 & 10.25 & 0.342 & 0.381 & 0.361 \\
\hline
\end{tabular}




\begin{tabular}{|c|c|c|c|c|c|c|c|c|c|}
\hline \multirow[t]{2}{*}{ Factors } & \multicolumn{3}{|c|}{ Grain Yield $\left(\mathrm{t} \mathrm{ha}^{-1}\right)$} & \multicolumn{3}{|c|}{ Straw Yield $\left(\mathrm{t} \mathrm{ha}^{-1}\right)$} & \multicolumn{2}{|l|}{$\mathrm{HI}$} & \multirow[b]{2}{*}{ Pooled } \\
\hline & 2010-11 & 2011-12 & Pooled & $\begin{array}{c}2010- \\
11\end{array}$ & $\begin{array}{c}2011- \\
12\end{array}$ & Pooled & $\begin{array}{c}2010- \\
11\end{array}$ & $\begin{array}{c}2011- \\
12\end{array}$ & \\
\hline $\begin{array}{l}100 \% \mathrm{NPK}+15 \mathrm{t} \\
\mathrm{ha}^{-1} \mathrm{FYM}+ \\
\text { micronutrient }\end{array}$ & 4.60 & 6.09 & 5.34 & 9.97 & 9.80 & 9.89 & 0.322 & 0.383 & 0.353 \\
\hline $125 \%$ NPK & 5.19 & 6.13 & 5.66 & 9.53 & 9.71 & 9.62 & 0.353 & 0.387 & 0.370 \\
\hline $\begin{array}{l}125 \% \text { NPK+15 t } \\
\text { ha }^{-1} \mathrm{FYM}\end{array}$ & 5.50 & 6.42 & 5.96 & 11.37 & 10.47 & 10.92 & 0.327 & 0.381 & 0.354 \\
\hline $\begin{array}{l}125 \% \text { NPK+15 t } \\
\text { ha }^{-1} \mathrm{FYM}+ \\
\text { micronutrient }\end{array}$ & 4.94 & 6.05 & 5.50 & 10.22 & 9.55 & 9.88 & 0.327 & 0.388 & 0.358 \\
\hline $150 \% \mathrm{NPK}$ & 5.74 & 6.47 & 6.10 & 12.12 & 10.41 & 11.27 & 0.327 & 0.383 & 0.355 \\
\hline $\begin{array}{l}150 \% \mathrm{NPK}+15 \mathrm{t} \\
\mathrm{ha}^{-1} \mathrm{FYM}\end{array}$ & 5.49 & 6.46 & 5.98 & 12.77 & 10.60 & 11.68 & 0.305 & 0.379 & 0.342 \\
\hline $\begin{array}{l}150 \% \mathrm{NPK}+15 \mathrm{t} \\
\mathrm{ha}^{-1} \mathrm{FYM}+ \\
\text { micronutrient }\end{array}$ & 5.21 & 6.54 & 5.87 & 11.92 & 10.71 & 11.31 & 0.305 & 0.379 & 0.342 \\
\hline Control & 2.49 & 1.96 & 2.22 & 4.30 & 3.38 & 3.84 & 0.390 & 0.368 & 0.368 \\
\hline $\mathrm{CD}(\mathrm{P}=0.05)$ & 0.39 & 0.30 & 0.24 & 1.67 & 0.52 & 0.86 & 0.027 & 0.012 & 0.015 \\
\hline
\end{tabular}

On the basis of pooled analysis, the maximum grain yield was recorded at 150 $\%$ NPK application (6.10 $\mathrm{tha}^{-1}$ ) followed by $15 \mathrm{t} \mathrm{ha}^{-1}$ FYM application along with $150\left(5.98 \mathrm{t} \mathrm{ha}^{-1}\right)$ and $125 \%\left(5.96 \mathrm{t} \mathrm{ha}^{-1}\right)$ NPK application (Table 1). The grain yield recorded at $150 \%$ NPK application was significantly higher than the yield noted in all combinations of $100 \%$ and $125 \%$ NPK applications except at $15 \mathrm{t} \mathrm{ha}^{-1}$ FYM along with $125 \%$ NPK application. There was no significant effect of micronutrient application on grain yield. All the treatments gave significantly higher grain yield over control in both years. Generally, the grain yield in 2011-12 across the treatments and varieties was higher than that in 2010-11. Straw yield was the maximum $(11.68 \mathrm{t}$ $\mathrm{ha}^{-1}$ ) at $150 \%$ NPK along with $15 \mathrm{t} \mathrm{ha}^{-1}$ FYM application followed by same level of NPK with micronutrient (11.31 $\left.\mathrm{t} \mathrm{ha}^{-1}\right)$. Generally, increasing the NPK level has increased the straw yield particularly with the treatments of $150 \%$ NPK application as compared to recommended fertilizer applications. Straw yield was higher in 201011 than in 2011-12 whereas trend in grain yield was just reverse. Maximum harvest index (0.375) was obtained with $100 \%$ NPK application followed by $125 \%$ NPK application (0.370). Generally, harvest index in 2011-12 was higher than that of 2010-11. This might be the reason for higher grain yield in the second year. 
Table 2. Effects of varieties, fertilizer rates, FYM and micronutrients on yield attributes of wheat

\begin{tabular}{|c|c|c|c|c|c|c|c|c|c|}
\hline \multirow[t]{2}{*}{ Factors } & \multicolumn{3}{|c|}{ Earhead $\mathrm{m}^{-2}$} & \multicolumn{3}{|c|}{ Grains earhead $^{-1}$} & \multicolumn{3}{|c|}{ 1000-grain weight, $\mathrm{g}$} \\
\hline & 2010-11 & 2011-12 & Pooled & 2010-11 & 2011-12 & Pooled & 2010-11 & 2011-12 & Pooled \\
\hline \multicolumn{10}{|l|}{ Varieties } \\
\hline DBW 17 & 522 & 456 & 489 & 28.12 & 31.15 & 29.64 & 35.33 & 41.18 & 38.26 \\
\hline DPW 621-50 & 505 & 430 & 467 & 27.49 & 33.63 & 30.57 & 35.2 & 39.15 & 37.16 \\
\hline $\mathrm{CD}(\mathrm{P}=0.05)$ & NS & NS & NS & NS & NS & NS & NS & NS & NS \\
\hline \multicolumn{10}{|l|}{ Fertilizer treatments } \\
\hline $100 \%$ NPK & 484 & 422 & 453 & 31.17 & 34.28 & 32.73 & 35.63 & 41.41 & 38.52 \\
\hline $\begin{array}{l}100 \% \mathrm{NPK}+15 \mathrm{tha}^{-} \\
{ }^{1} \mathrm{FYM}\end{array}$ & 506 & 455 & 480 & 31.05 & 31.62 & 31.34 & 35.49 & 41.88 & 38.69 \\
\hline $\begin{array}{l}100 \% \mathrm{NPK}+15 \mathrm{t} \text { ha } \\
{ }^{1} \mathrm{FYM}+\text { micronutrient }\end{array}$ & 514 & 446 & 480 & 26.50 & 32.71 & 29.61 & 34.26 & 42.34 & 38.30 \\
\hline $125 \% \mathrm{NPK}$ & 535 & 451 & 493 & 28.49 & 34.08 & 31.28 & 34.51 & 40.13 & 37.32 \\
\hline $\begin{array}{l}125 \% \mathrm{NPK}+15 \mathrm{t} \text { ha } \\
{ }^{1} \mathrm{FYM}\end{array}$ & 532 & 468 & 500 & 29.58 & 34.11 & 31.85 & 35.32 & 40.41 & 37.87 \\
\hline $\begin{array}{l}125 \% \mathrm{NPK}+15 \mathrm{t} \text { ha } \\
{ }^{1} \mathrm{FYM}+\text { micronutrient }\end{array}$ & 508 & 425 & 466 & 28.32 & 35.85 & 32.04 & 34.80 & 40.82 & 37.81 \\
\hline $150 \%$ NPK & 589 & 426 & 557 & 28.58 & 32.25 & 30.41 & 34.41 & 38.54 & 36.47 \\
\hline $\begin{array}{l}150 \% \text { NPK }+15 \text { t ha' } \\
{ }^{1} \text { FYM }\end{array}$ & 556 & 466 & 511 & 29.02 & 35.96 & 32.49 & 34.62 & 38.99 & 36.81 \\
\hline $\begin{array}{l}150 \% \mathrm{NPK}+15 \mathrm{t} \text { ha } \\
{ }^{1} \mathrm{FYM}+\text { micronutrient }\end{array}$ & 564 & 489 & 526 & 26.57 & 34.62 & 30.59 & 35.31 & 39.21 & 37.26 \\
\hline Control & 346 & 283 & 315 & 18.89 & 18.45 & 18.67 & 38.31 & 37.92 & 38.11 \\
\hline $\mathrm{CD}(\mathrm{P}=0.05)$ & 51 & 63 & 39 & 3.12 & 4.76 & 2.88 & 1.9 & 1.61 & 1.22 \\
\hline
\end{tabular}

On pooled basis, application of $150 \%$ NPK resulted in the maximum and significantly higher earhead $\mathrm{m}^{-2}$ (557) compared to the other treatments except $150 \%$ NPK $+15 \mathrm{t} \mathrm{ha}^{-1}$ FYM + micronutrient application (526). There was an increase in number of earhead $\mathrm{m}^{-2}$ with application of $150 \%$ fertilizer than 100 and $125 \%$ fertilizer applications. In the first year (2010-11), the number of earhead $\mathrm{m}^{-2}$ was higher than in the second year (2011-12). Recommended fertilizer application has produced the maximum (32.73) grains earhead ${ }^{-1}$ followed by $150 \% \mathrm{NPK}+15 \mathrm{tha}^{-1}$ FYM application (32.49) as compared to other treatments. The number of grains earhead $^{-1}$ was higher during 2011-12 in all cases (Table 2). This was probably due to the reason that earhead $\mathrm{m}^{-2}$ was lower in 2011-12 than in 2010-11. The maximum 1000-grain weight (38.69 g) was recorded with application of $100 \%$ NPK along with $15 \mathrm{t} \mathrm{ha}^{-1}$ FYM application followed by 100\% NPK application alone $(38.52 \mathrm{~g})$. Generally, the 1000-grain weight in 2011-12 was higher than in 2010-11 across the treatments. The number of grains $\mathrm{m}^{-2}$ was the maximum with application of $150 \%$ NPK (16759) followed by same treatment with addition of $15 \mathrm{t} \mathrm{ha}^{-1}$ FYM (16215). On the other hand lowest grains $\mathrm{m}^{-2}$ was recorded with recommended dose of 
fertilizer $+15 \mathrm{t} \mathrm{ha}^{-1} \mathrm{FYM}+$ micronutrient application (13910). Some lodging was observed during both the years under study and more prone during the first year of study. Maximum lodging was observed in micronutrient applied treatments at 100, 125 and $150 \%$ NPK application during 2010-11. The maximum agronomic efficiency was obtained with recommended dose of fertilizer application $(13.64 \mathrm{~kg}$ grain $\mathrm{kg}^{-1}$ fertilizer). Increasing fertilizer rates decreased the agronomic efficiency. Addition of $15 \mathrm{t} \mathrm{ha}^{-1} \mathrm{FYM}$ also resulted in decreased agronomic efficiency due to 75 $\mathrm{kg} \mathrm{N}$ addition in these treatments $(0.5 \% \mathrm{~N}$ in FYM). In 2011-12, the agronomic efficiency for all the treatments was higher than in 2010-11 due to higher grain yield (Table 3).

Table 3. Effects of varieties, fertilizer rates, FYM and micronutrients on the number of grains $\mathrm{m}^{-2}$, lodging and agronomic efficiency

\begin{tabular}{|c|c|c|c|c|c|c|c|c|c|}
\hline \multirow[t]{2}{*}{ Factors } & \multicolumn{3}{|c|}{ Number of grains $\mathrm{m}^{-2}$} & \multicolumn{2}{|c|}{ Lodging $(\%)$} & \multirow[b]{2}{*}{ Pooled } & \multicolumn{3}{|c|}{$\begin{array}{l}\text { Agronomic Efficiency (kg } \\
\text { grain } \mathrm{kg}^{-1} \text { fertilizer) }\end{array}$} \\
\hline & 2010-11 & 2011-12 & Pooled & 2010-11 & 2011-12 & & 2010-11 & 2011-12 & Pooled \\
\hline \multicolumn{10}{|l|}{ Varieties } \\
\hline DBW 17 & 14697 & 14291 & 14494 & - & - & - & - & - & - \\
\hline DPW 621-50 & 13765 & 14621 & 14193 & - & - & - & - & - & - \\
\hline $\mathrm{CD}(\mathrm{P}=0.05)$ & NS & NS & NS & - & - & - & - & - & - \\
\hline \multicolumn{10}{|l|}{$\begin{array}{l}\text { Fertilizer } \\
\text { treatments }\end{array}$} \\
\hline $100 \%$ NPK & 14875 & 14468 & 14671 & 0.00 & 0.00 & 0.00 & 11.22 & 16.04 & 13.64 \\
\hline $\begin{array}{l}100 \% \text { NPK+15 tha } \\
{ }^{1} \text { FYM }\end{array}$ & 15431 & 14363 & 14897 & 5.60 & 10.20 & 7.90 & 9.20 & 12.42 & 10.81 \\
\hline $\begin{array}{l}100 \% \mathrm{NPK}+15 \mathrm{t}^{-} \\
{ }^{1} \mathrm{FYM}+ \\
\text { micronutrient }\end{array}$ & 13448 & 14372 & 13910 & 33.50 & 7.50 & 20.50 & 6.49 & 12.70 & 9.60 \\
\hline $125 \%$ NPK & 15061 & 15267 & 15164 & 7.50 & 3.40 & 5.50 & 8.67 & 13.33 & 11.00 \\
\hline $\begin{array}{l}125 \% \text { NPK+15 tha' } \\
{ }^{1} \text { FYM }\end{array}$ & 15565 & 15964 & 15764 & 4.30 & 5.70 & 5.00 & 7.77 & 11.50 & 9.64 \\
\hline $\begin{array}{l}125 \% \mathrm{NPK}+15 \mathrm{t}^{-} \\
{ }^{1} \mathrm{FYM}+ \\
\text { micronutrient }\end{array}$ & 14219 & 14864 & 14541 & 45.20 & 7.60 & 26.40 & 6.34 & 10.55 & 8.44 \\
\hline $150 \%$ NPK & 16714 & 16805 & 16759 & 10.20 & 4.50 & 7.40 & 8.67 & 12.03 & 10.35 \\
\hline $\begin{array}{l}150 \% \mathrm{NPK}+15 \mathrm{tha}^{-} \\
{ }^{1} \mathrm{FYM}\end{array}$ & 15840 & 16590 & 16215 & 8.60 & 3.40 & 6.00 & 6.68 & 10.00 & 8.34 \\
\hline $\begin{array}{l}150 \% \mathrm{NPK}+15 \text { tha- } \\
{ }^{1} \mathrm{FYM}+ \\
\text { micronutrient }\end{array}$ & 14728 & 16693 & 15710 & 35.40 & 4.60 & 20.00 & 6.04 & 10.17 & 8.11 \\
\hline Control & 6430 & 5176 & 5803 & - & - & - & - & - & - \\
\hline $\mathrm{CD}(\mathrm{P}=0.05)$ & 750 & 857 & 560 & - & - & - & - & - & - \\
\hline
\end{tabular}




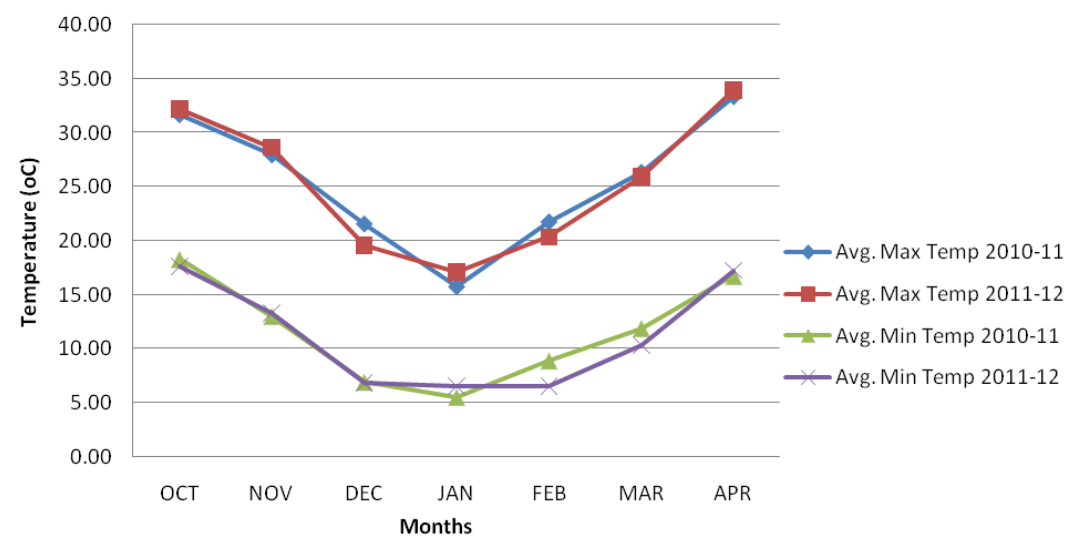

Figure 1. Average Maximum and Minimum Monthly Temperature During the Period of Experiment

\section{DISCUSSION}

Yield of a crop could be maximized when there is no limiting factor affecting the yield whether biotic or abiotic factor (s) during the entire crop cycle. This is an ideal situation, which seldom occur in the nature. Generally, inputs are applied when there is a visible symptom of any deficiency particularly nitrogen and irrigation. In the present study, variety DBW 17 was a head of DPW 621-50 in terms grain yield $(4.93 \%)$, straw yield $(6.31 \%)$ and $\mathrm{HI}(1.12 \%)$. Varietal differences in grain yield were also reported by Tripathi et al. (2004). Application of $150 \%$ NPK resulted in $7.7 \%$ increase in grain yield than the recommended fertilizer dose and the next best yielding treatment was $15 \mathrm{t} \mathrm{ha}^{-1} \mathrm{FYM}$ application $+125 \%\left(5.96 \mathrm{t} \mathrm{ha}^{-1}\right)$ or $150(5.98 \mathrm{t}$ $\mathrm{ha}^{-1}$ ) NPK applications. This shows that there is a need to re-look at the recommended fertilizer doses and use of FYM for maximizing wheat yield. In comparison to $150 \%$ NPK alone, application of FYM $15 \mathrm{t} \mathrm{ha}^{-1}$ along with $150 \%$ NPK could not increase the grain yield, however, biomass was increased which is reflected in higher straw yield. This might be due to fact that photosynthates may not be translocated to grain yield as evident from lower HI, despite similar lodging behavior. Similar results were reported by Dekhane et al. (2015). These results might be due to that organic manure improves soil properties and causes slow release of nutrients from fertilizers (Sharma et al., 2015). During the 2011-12 crop cycle, grain yield was higher than 2010-11 due to higher 1000-grain weight, HI and grains earhead $^{-1}$ across the treatments. In the second year (2011-12), the crop produced less number of earhead $\mathrm{m}^{-2}$ than previous year of study. Approximately $2^{0} \mathrm{C}$ lower average minimum temperatures in February and March were recorded during 2011-12 crop cycle as compared to 2010-11 (Figure 1). This might be a reason for higher productivity and high yield attributing parameters particularly 1000-grain weight, HI and number of grains earhead ${ }^{-1}$ during the second year of experimentation. Additionally, low grain yield during the first year of study was owing to lodging in 
many plots as compared to the second year of study. The maximum lodging was observed to the tune of $26.4 \%$ which reduced the grain yield up to $9.9 \%$ as compared to the maximum grain yield. This confirms earlier finding that lodging of crops reduces the grain yield to a great extent (Kheiralla et al., 1993 and Tripathi et al., 2004). Agronomic efficiency decreased as fertilizer doses were increased. The decrease in NUE with increasing fertilizer rates can be attributed to the rise of grain yield less than the $\mathrm{N}$ supply in soil by fertilizer application (Lopez-Bellido and Lopez-Bellido, 2001).

\section{CONCLUSION}

The study revealed that there were no limiting factors during the crop cycles except lodging. Higher rate of fertilizers i.e. $150 \%$ recommended rate $(100 \%)$ increased the grain yield of wheat despite the lodging problem. It is suggested that breeders should develop more robust and lodging resistant genotypes responsive to higher soil fertility levels for maximizing the wheat grain yield. Lower minimum temperature prevailing during grain filling period in the second year of experimentation increased the grain yield due to higher 1000-grain weight and number of grains earhead ${ }^{-1}$. Inclusion of FYM with chemical fertilizer resulted in lower agronomic efficiency.

\section{REFERENCES}

Dekhane, S. S., Patil, N. B., Jadhav, K. P. and Patel, D. J. 2015. Effect of organic and inorganic fertilizers on growth and yield of paddy. International Journal of Tropical Agriculture, 33(1): 149-51

Fischer, R. A., and Stapper, M. 1987. Lodging effects on high yielding crops of irrigated semi-dwarf wheat. Field Crops Research, 17: 245-258.

Hobbs, P., Sayre, K. D. and Monasterio, J. I. Ortiz. 1997. Increasing wheat yield through agronomic means. Paper presented at International Group Meeting on "Wheat Research needs beyond 2000, held at Karnal, India,on 12-14 August 1997.

Kheiralla, K. A., Mehdi, E. E. and Dawood, R. A. 1993. Evaluation of some wheat cultivars for traits related to lodging resistance under different levels of nitrogen. Assiut Journal of Agricultural Sciences, 24: 257-271

Kumara, B. H., Antil, R. S. and Dev Raj. 2013. Long term effects of nutrient management on soil health and crop productivity under Pearl millet wheat cropping system. Indian Journal of Fertilizers, 9(12): 86-97

Lopez-Bellido, R.J. and Lopez-Bellido, L. 2001. Efficiency of nitrogen in wheat under Mediterranean condition: effect of tillage, crop rotation and $\mathrm{N}$ fertilization. Field Crops Research, 71(1): 31-64

Sharma, V., Khan, M. A. and Shukla, R. K. 2015. Organic agro-inputs: "possible substitute of chemical fertilizers in production of wheat (Triticum aestivum L.)". Global Journal of Multidisciplinary Studies, 4(8): 170-77

Tripathi, S. C., Sayre, K. D., Kaul, J. N. and Narang, R. S. 2004. Lodging behavior and yield potential of spring wheat (Triticum aestivum L.): Effects of ethephon and genotypes. Field Crops Research, 87 (2-3):207-220 